\begin{tabular}{l} 
Bentham OPEN The Open Construction and Bulding \\
CrossMark \\
Content list available at: www.benthamopen.com/TOBCTJ/ \\
DOI: $10.2174 / 1874836801610010525$ \\
\hline
\end{tabular}

RESEARCH ARTICLE

\title{
Experimental Study on Properties of Steel-plastic Geogrids and their Application in Supporting Engineering
}

Qingbiao Wang ${ }^{*}, 1,2,3$, Rongshan Lü ${ }^{1}$, Yingchun Kong ${ }^{1}$, Lingyu Tang ${ }^{1}$, Fei Xie ${ }^{1}$, Qingli Kong ${ }^{1}$, Junjie Zhang ${ }^{1}$, Tangsha Shao ${ }^{1}$, Qingkai Zhu ${ }^{1}$, Shuyi Xu ${ }^{1}$, Zhongjing $\mathrm{Hu}^{1}$, Yun Bai ${ }^{1}$, Xunmei Liang ${ }^{3}$ and Shide $\mathrm{Lu}^{3}$

${ }^{I}$ College of Civil Engineering and Architecture, Shandong University of Science and Technology, Qingdao Shandong 266590, China

${ }^{2}$ Department of Resource and Civil Engineering, Shandong University of Science and Technology, Tai'an, Shandong 271019, China

${ }^{3}$ Tai'an Road Engineering Materials Co., Ltd., Tai'an, Shandong, 271019, China

Received: July 14, 2016

Revised: September 15, 2016

Accepted: September 30, 2016

\begin{abstract}
Steel-plastic geogrid greatly improves the stability of surrounding rock in the supporting project due to the qualities, such as high strength, high toughness and less creep deformation. Through the geogrid mechanical properties analysis, tensile strength, deformation and creep test and field experiment and so on, we researched and analyzed steel-plastic geogrids' characteristics and supporting effect, and concluded the influencing factors of steel-plastic geogrids' characteristics, load-time curve and the steel-plastic geogrids' variation under different temperature. We explained steel-plastic geogrids' supporting effect through specific examples of projects. The results of the studies are listed as follows: (1) Steel-plastic geogrid has good resistance to deformation and node failure of roadway surrounding rock deformation, which has good tensile property, creep property and deflection performance; (2) It is feasible to support the surrounding rock by forming a whole combined joint support with steel- plastic geogrid and high-strength prestressed anchor rod.
\end{abstract}

Keywords: Creep, Deflection, Mechanical properties, Plastic geogrid, Rock support, Tensile properties.

\section{INTRODUCTION}

With the advantages of high strength, good durability, convenient construction, geogrid has been widely used in highway, railway, mine and other fields. When it is applied as supporting structure, geogrid mainly through its tensile strength to bear the load from the soil plays a role of the project. But as a kind of new material, research on the mechanical properties is still at the beginning stage. Similarly, steel grating in roadway support applied research is still blank.

A lot of people have studied the application of metal mesh as the anchor net in support. But almost no one is involved in the application of the steel plastic geogrid as anchor net support. In the 1960s, L.V. Rabcewic [1] summarized and put forward a new construction method for Austria tunnel with many years' experiences of tunnel engineering construction in Austria. The construction method of flexible support and active support method, the soft rock roadway has a certain guiding significance, has been widely used in the design and construction of underground engineering Based on the classical elastic-plastic theory of surrounding rock, many scholars have carried out a lot of research and improvement in the domestic and international $[2,3]$.

\footnotetext{
* Address correspondence to this author at the Department of Resource and Civil Engineering, Shandong University of Science and Technology, Tai'an, Shandong 271019, China; Tel:+8618805381111; E-mail: 1349725165@qq.com
} 
On the base of the experimental research, Tannant. D. D. [4, 5] studied the welding wire mesh reinforcement, and found that the net in the anti-deformation ability depended on the plate shape and plate relative to the nets in the direction, and the mesh number of the load transfer located in the pallet. Since the 90's in twentieth century, the development of the domestic and international has been gradually developed with the support of the cable and the anchor net belt [6 - 9]. By using bolt support on the initial pressure of the surrounding rock to support the foundation, strength and stiffness of the two supporting measures increase to jointly support the surrounding rock stress, this by improving the supporting strength to maintain the long-term stability of the tunnel. Supporting measures were taken to the anchor, grouting and sealing metal bracket or concrete lining structure to form a different form of joint support [10 $14]$.

In view of the metal mesh selection and network method in coal mine bolt mesh shotcrete support, Lin Jian and Sun Zhiyong [15] used laboratory test method to study the stress state, deformation condition and supporting function of the common metal mesh of the bolt support. According to the bolt fracture, appeared in Dongtan coal mine roof net local roadway deformation serious tear strip even collapse, Deng Xiaolin [16] optimizes the anchor net support technology in deep well. Therefore, combined with a variety of theories and methods, research on mechanical properties of steel grating and the supporting effect is very necessary.

From the above results, we know that there are almost no researches of the steel-plastic geogrids as the anchor of the supporting mechanism and method. Therefore, this paper introduced tests and analysis of steel-plastic geogrids' tensile strength, deflection performance and creep performance. Steel-plastic geogrid was applied successfully in roadway, and it was verified that the steel-plastic geogrids could replace metal mesh to support in roadway.

\section{OVERVIEW OF PLASTIC GEOGRID}

\subsection{Concept and Scope of Application}

Based on plastic geogrid, the steel-plastic geogrid is made of high strength steel wires processed specially and PE or PP and other additives. Steel wires are wrapped by PE or PP by special fusing, then these form compound and high strength tensile bands with rough surface, and the followed procedure is that longitudinal and transverse bands experience a knitting procedure into a system at certain distance. A special welding technology is used to bond the junction points into the steel-plastic geogrid. Changing the diameters of steel wires and quantity improves the tensile strength of geogrid. The steel-plastic geogrid can enhance tensile strength of geogrid, and is more good at resisting creep properties, and prolong the service life of the grid, which is suitable for coal mine, highway, railway, airport, well irrigation, civil construction and so on [17 - 20].

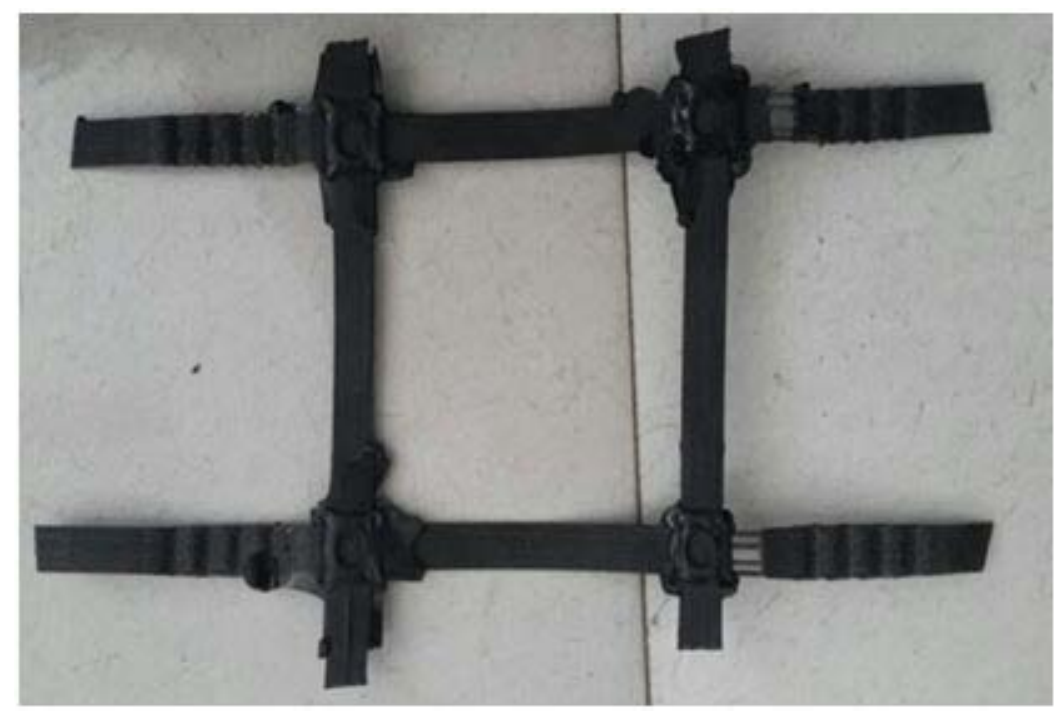

Fig. (1). The steel-plastic geogrid.

\subsection{Mechanical Performance Index}

In the design and construction process, due to the different load, the mechanical performance evaluation indexes of 
steel-plastic geogrids are also different. The mechanical properties of the steel-plastic geogrid (Fig. 1) include tensile strength, friction test intensity, tensile strength and the interaction between the fillers and so on [21]. The Mechanical performance indexes are shown in Tables $\mathbf{1}$ and $\mathbf{2}$.

Table 1. Main index of the $0.7 \mathrm{mmx} 12$ geogrids.

\begin{tabular}{|c|c|}
\hline Project & Type and Specification \\
\hline Vertical (horizontal) to tensile strength $(\mathrm{kN} / \mathrm{m})$ & $\geq 128.0$ \\
\hline The tensile strength of the $2 \%$ longitudinal strain $(\mathrm{kN} / \mathrm{m})$ & $\geq 30.4$ \\
\hline The tensile strength of the $5 \%$ longitudinal strain $(\mathrm{kN} / \mathrm{m})$ & $\geq 61.2$ \\
\hline Peak strain $/ \%$ & $\leq 15.5$ \\
\hline Creep ultimate strength at $20^{\circ}(\mathrm{kN} / \mathrm{m})$ & $\geq 45.3$ \\
\hline
\end{tabular}

\section{TEST ANALYSES}

Considering that the support effect is influenced by different temperatures, loads and fillers in engineering application, the tensile properties of geogrid are different. Therefore, the test of single and double geogrids pull out test of the above mentioned factors is carried out, and the strength of the steel-plastic geogrids is studied [22].

\subsection{Tensile Strength}

The steel-plastic geogrid is a flexible material, and the tensile strength is the main characteristic of the material of the synthetic material. The main parameters include that: the tensile strength of the longitudinal and transverse tensile strength is far greater than $50 \mathrm{kN} / \mathrm{m}$, the longitudinal and transverse elongation are no more than $13 \%$, and the tensile strength of the elongation at $5 \%$ is much greater than $35 \mathrm{kN} / \mathrm{m}$.

In order to study the effect of different tensile rates on the tensile properties of steel-plastic geogrids, we selected three kinds of different specifications of the steel plastic geogrids in the uniform and different strain rates $(50,10,1,0.1$, $0.05 \mathrm{~mm} / \mathrm{min}$ ) of tensile in experiment research. Test equipment was used for the DR028J universal material testing machine. The experiment was carried out at $(20+2)^{\circ} \mathrm{C}$ constant temperature and $(60+5) \%$ relative humidity conditions, and used the fixture to clamp the steel-plastic geogrid by the universal testing machine. The whole experiment process is controlled by universal testing machine.

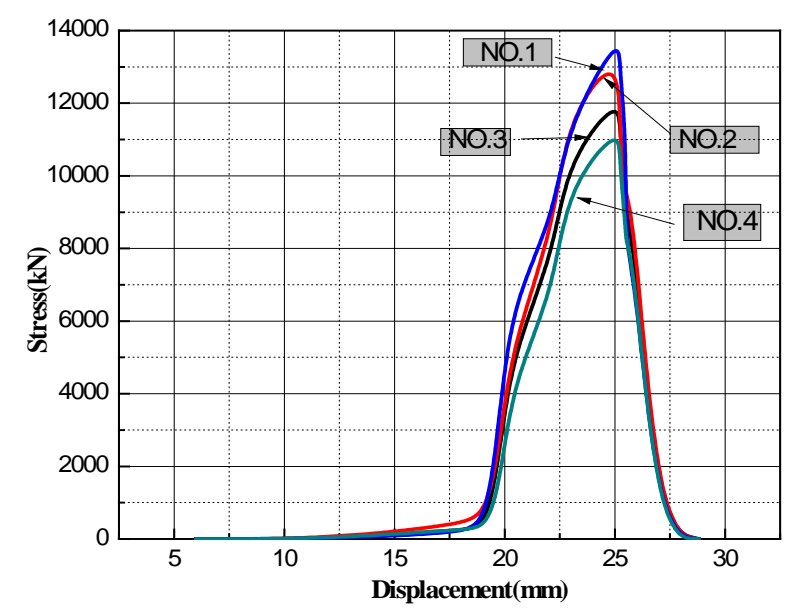

Fig. (2). Tensile test result of geogrids at a steady speed.

As we can see from Fig. (2), the four groups of steel-plastic geogrid stretching process can be roughly divided into three stages: low load and large deformation stage, stage of small high load deformation and fracture stage. At the beginning of loading process low load and large deformation stage: tensile load was small, the displacement of tensile deformation was large, and 4 groups had reached the final tensile testing of about $19 \mathrm{~mm}$; and then had entered the second stage high load small deformation stage. In this stage, with the increase of loading, the displacement and deformation of geogrid were increasing gradually. It could be seen from the Fig. (2), the tensile curves increased, but at the same change of loading, the displacement of the second phase is smaller than the first stage, and tensile maximum length of the NO.1 group is only $6 \mathrm{~mm}$; when the loading exceeded $11 \mathrm{kN}$, the four groups had entered the third stage 
fracture stage: in this stage, the wires were destroyed by root, the tensile curve decreased, and the tensile strength decreased rapidly until 0 . It could be known from the analysis: the tensile strength of steel-plastic geogrid was influenced obviously by steel wires, and wires were destroyed, thereby decreasing the geogrid tensile strength.

Table 2. Mechanical properties of bidirectional steel plastic geogrid.

\begin{tabular}{|c|c|c|c|c|c|c|c|}
\hline \multirow{2}{*}{ Type } & $\begin{array}{c}\text { Per meter tensile yield } \\
\geq(\mathbf{k N} / \mathbf{m})\end{array}$ & \multicolumn{2}{|c|}{ Nominal elongation rate $\leq(\%)$} & \multicolumn{2}{|c|}{ The tensile force at $\mathbf{2 \%}$ elongation $\geq(\mathbf{k N} / \mathbf{m})$} & \multirow{2}{*}{ Width(m) } \\
\cline { 2 - 8 } & Longitudinal & Transverse & Longitudinal & Transverse & Longitudinal & Transverse & \\
\hline GSZ60-60 & 60 & 60 & 3 & 3 & 54 & 54 & 6.0 \\
\hline
\end{tabular}

\subsection{Deflection Test}

Due to the high flexibility of the steel-plastic geogrid, we could not measure the deflection of steel-plastic geogrid directly, so the geogrid was placed on a concrete slab, and the deflection tests were carried out. In order to guarantee the reliability of the test data, and take the influence factor into consideration, we made 4 plates for test. These plates were divided into 2 types, which were added to the steel-plastic geogrid, and phi 6-Q235 metal mesh. Concrete plate specifications were $1000 \mathrm{~mm} \times 1000 \mathrm{~mm} \times 100 \mathrm{~mm}$. The concrete slab is shown in Fig. (3).

The TLD-JG600 manhole cover press machine was used in the experiment, which was provided by LU DA of Shandong, and the machine consisted of a portal frame, cylinder, oil source and servo measurement control system. It is shown in Fig. (4). Oil source consists of three parts: Taiwan group pump motor, Italy Matsu Ki pump and Athos servo valve. Control system includes a spoke compound sensor, photoelectric encoder, temperature monitor, Lenovo machine operating procedures. This equipment has many advantages: design is reasonable, performance is reliable, structure is firm and the data are accurate. The maximum load was $600 \mathrm{kN}$ and the displacement can reach $400 \mathrm{~mm}$.

After the completion of the maintenance, the specimen is transported to the test device position. The hydraulics of the test machine were changed to the highest level. Specimen was placed on the supporting by forklift, and test operator fine-tuned the location of the specimen to ensure that the specimen was located in the middle, so the force became uniform. According to the experiment requirements, such as the adjusting of test equipment and the placement of test plate, and the sample was loaded by hydraulic lift. When the pressure plate contacted specimen and the stress started to change, all the dates were cleared. In order to reduce specimen surface roughness caused by stress concentration and obtain test data accurately, we chose a smaller load as a control load $(1 \mathrm{kN}, 0.7 \mathrm{kN}$ and $0.6 \mathrm{kN})$.

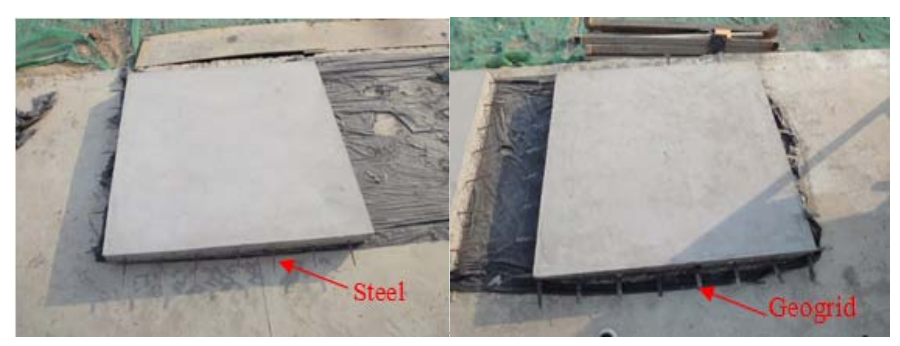

(a)

(b)

Fig. (3). Concrete slab specimens.

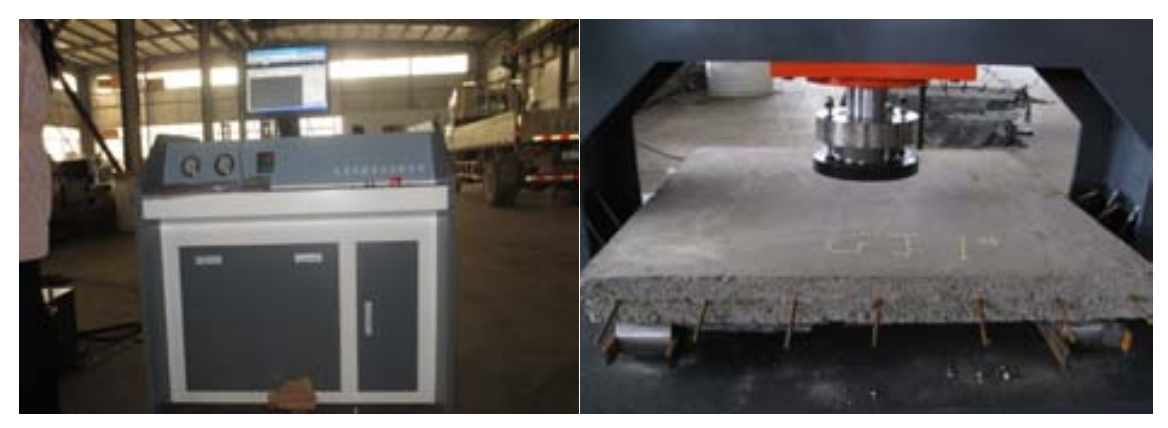

Fig. (4). The TLD-JG600 manhole cover press machine. 


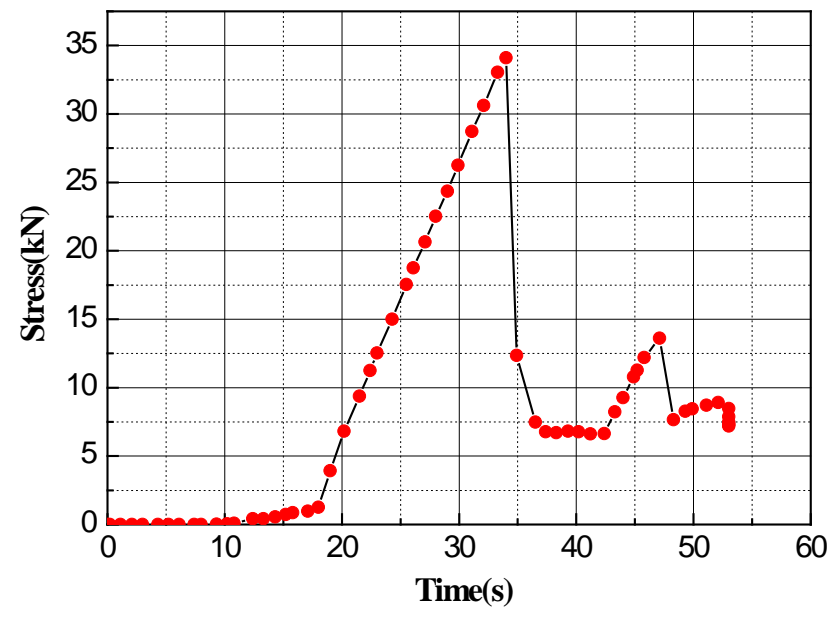

Fig. (5). Relationship between the Stress and Time of GSW-1 specimens.

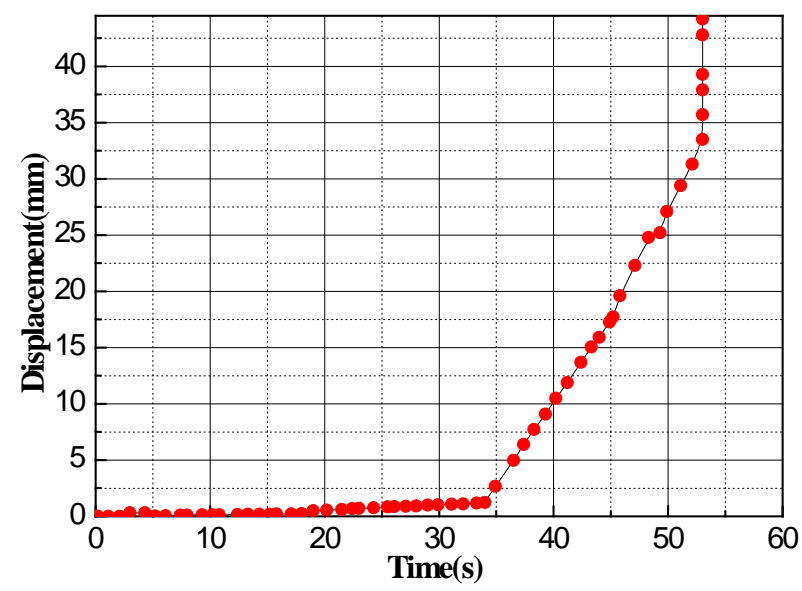

Fig. (6). Relationship between the Strain and Time of GSW-1 specimens.

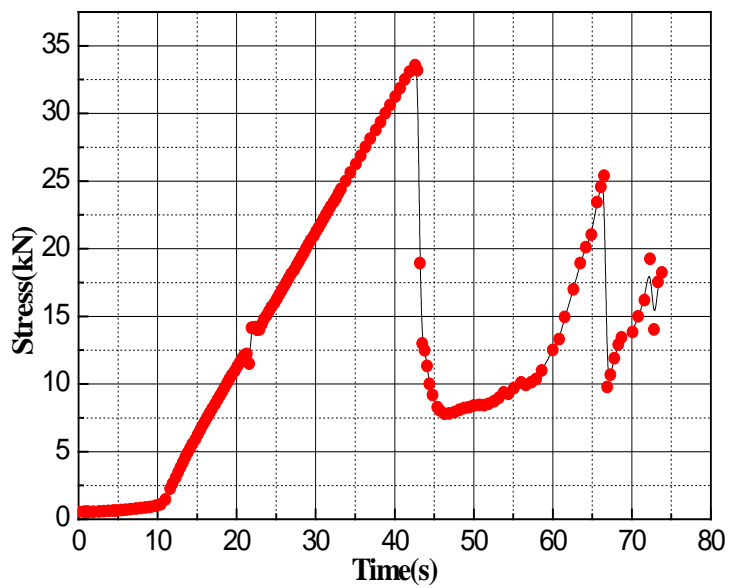

Fig. (7). Relationship between the Stress and Time of GSW-2 specimens. 


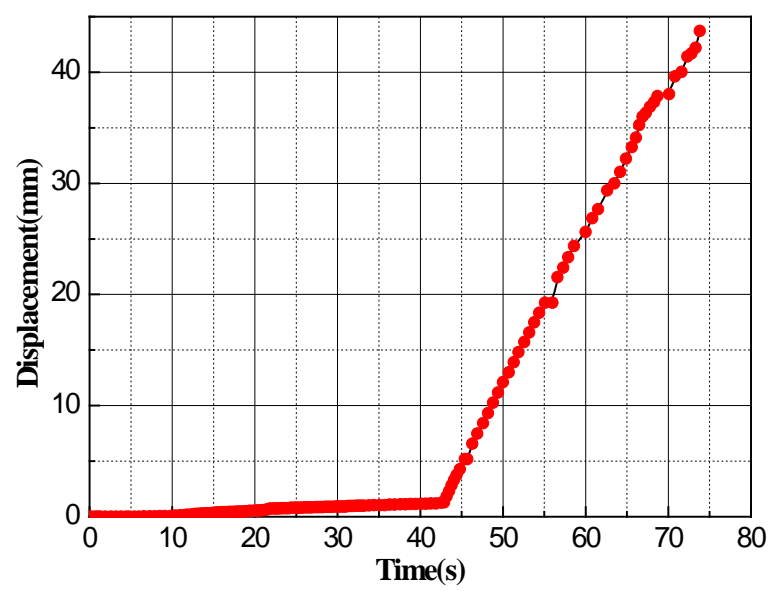

Fig. (8). Relationship between the Strain and Time of GSW-2 specimens.

As we can see from Figs. (5-8).

1. For GSW-1 and GSW-2, the two same steel-geogrids slab stress changes were similar. From the beginning of the applied loading to the load applied to the 10s, GSW-1 could withstand the pressure, and changes were slow and only grew to $1 \mathrm{kN}$, the displacement almost no change. When the loading time reached 20s, stress began to increase and the plate began to crack. At the same time, stress decreased with the expansion of cracks. The steel geogrid began to play a role, and stress increased again. When the loading time reached $45 \mathrm{~s}$, stress reached the maximum, $34.1 \mathrm{kN}$, and displacement reached the maximum $44.2 \mathrm{~mm}$.

2. Due to the inclined plate, its stress was uneven. The stress of GSW-2 was rapidly grown in 10s, but there was no displacement changing. When the applied load time was up to 40s, GSW-2 appeared to crack and the withstand stress began to decline, and the displacement began to increase. As cracks continued to increase, the metal mesh began to play a role, letting the stress increase, but the stress only reached $27.5 \mathrm{kN}$.

\subsection{Creep Test}

The so-called geogrid creep characteristic is the geogrid deformation with the continuation of time in the case of the external load. Geogrid is made of a series of complex processes and it has a grid structure, which has a direct effect on the long-term stability of reinforced earth structures [23]. The creep effect of the reinforced structure can lead to the change of stress state, and then cause the engineering loss of the whole stability. Therefore, the creep performance of the geogrid is the key to the stability of the geogrid tensile strength. In practical engineering application, due to the influences of different temperature and loading, the geogrids will be the creep deformation, so that the geogrid reinforcement function is greatly weakened or even the buildings lose its overall stability. For the steel-plastic geogrid, under the same tension $(50 \mathrm{kN} / \mathrm{m}), 20$ DEG C, 40 DEG C two different environment temperature conditions, we obtained steel-plastic geogrids' creep curve by test, as shown in Fig. (9).

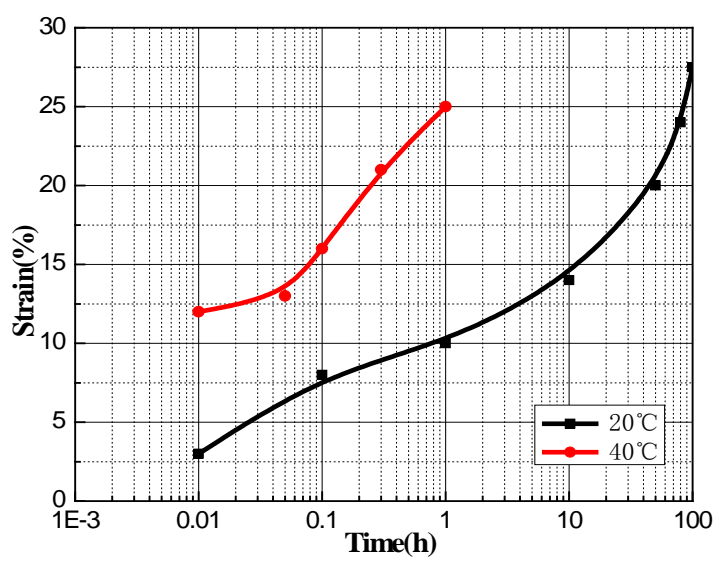

Fig. (9). The time -strain curve (different temperature). 
Through the analysis of Fig. (9), we could know that the strain spent 100 hours reaching 20 at 20 DEG C, but in 40 DEG C, only 0.5 hours is enough. The temperature had a great influence on steel-plastic geogrids' creep, and the strain value increased with the increasing of temperature.

\section{SUPPORT THEORIES}

Anchor net support mainly use prestressed anchor (resin bolt, an end anchor head mechanical bolt) and anchor (metal), the selected anchoring force should be very strong, which can carry real time, after installation of surrounding rock prestressing [24].

In the broken soft rock roadway, bolt support is difficult to form a stable and effective load bearing structure, which is difficult to control the strong deformation of this kind of roadway, and it is not enough to ensure the overall stability of the roadway. Elastic-plastic theory analysis method is to study the deformation and failure of roadway surrounding rock, and is the most original and one of the most classical methods, which is the theoretical basis of the research on the deformation and failure mechanism of roadway surrounding rock [25 - 29].

The roadway surrounding rock is generally in a low confining pressure environment, and under this condition, the strain softening phenomenon generally occurs. The correlation test $[30,31]$ showed that the residual strength increased with the increase of confining pressure, and it showed a strong sensitivity to confining pressure.

Metal frame is the most commonly used method in soft rock tunnel. It is through the provision of passive radial support force, directly acting on the surface of the roadway surrounding rock, to balance the deformation of the surrounding rock, the surrounding rock deformation. Support technology is a common form of support in deep rock roadway [32 - 39].

The high quality of the anchor net can effectively control rock deformation, and boost to squeeze into the tunnel rock; it is an important measure to ensure the anchoring effect of bolts. And its main functions are as following: (1) preventing cataclysmic rock mass caving, (2) separating load from non-anchoring rock to the anchor, (3) anchor net cradling the broken rock. Although roadway surrounding rock has been broken, due to gravel bulking effect and transmit the force of the role of the media, the roadway deep surrounding rock remains a triaxial stress state, greatly improving the rock mass of residual strength (as shown in the Fig. 10) [40 - 43].

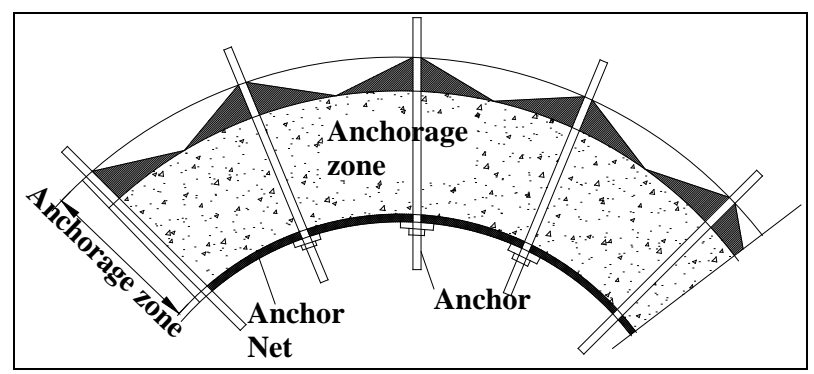

Fig. (10). Anchor net support and surrounding rock interaction.

\section{ENGINEERING EXAMPLES}

\subsection{Engineering Survey}

Shandong Hualian mining is located in Yiyuan, Shandong Province. Most of the rock roadway lay in the complex geological conditions of rock. The tunnel buried is in more than $1000 \mathrm{~m}$, and tunnels are in great depth, rock with large deformation and high pressure conditions. The dip angle is from $25^{\circ}$ to $30^{\circ}$. The uniaxial compressive strength is 2.2 $\mathrm{MPa}$. The traditional support method is more and more difficult to control in the roadway support engineering so that many technical problems are encountered. Hualian ditch mine mainland layer can be divided into four engineering geological petro-fabric: Quaternary loose rock formation, Cambrian limestone shale rock group, Taishan Mountain Group metamorphic rock and igneous rock group, which is decided by the above characteristics. The Quaternary loose rock group stability is poor. Cambrian limestone shale rock hard to semi hard, but close to the Han Wang rupture, rock crushing rock quality classes VI to V level; metamorphic rock group and magmatic rock quality of grade III, ore produced for the Taishan Mountain Group wild goose Ling Guan formation, surrounding rock strength is higher. 


\subsection{Supporting Construction}

\subsubsection{Hang Network}

According to the tunnel blasting footage and construction convenience, this section of the test steel grating linked to design the whole section hanging design of steel gratings method, from the top in turn laid on both sides, termination on the side of the rock to help foot. Geogrid width is arranged from $1.6 \mathrm{~m}$ to $2.0 \mathrm{~m}$, and length is same as tunnel section perimeter. Geogrid lap width is $15 \mathrm{~cm} \sim 20 \mathrm{~cm}$, and nylon ties are used to fix geogrids reinforced with binding, as shown in Fig. (11).

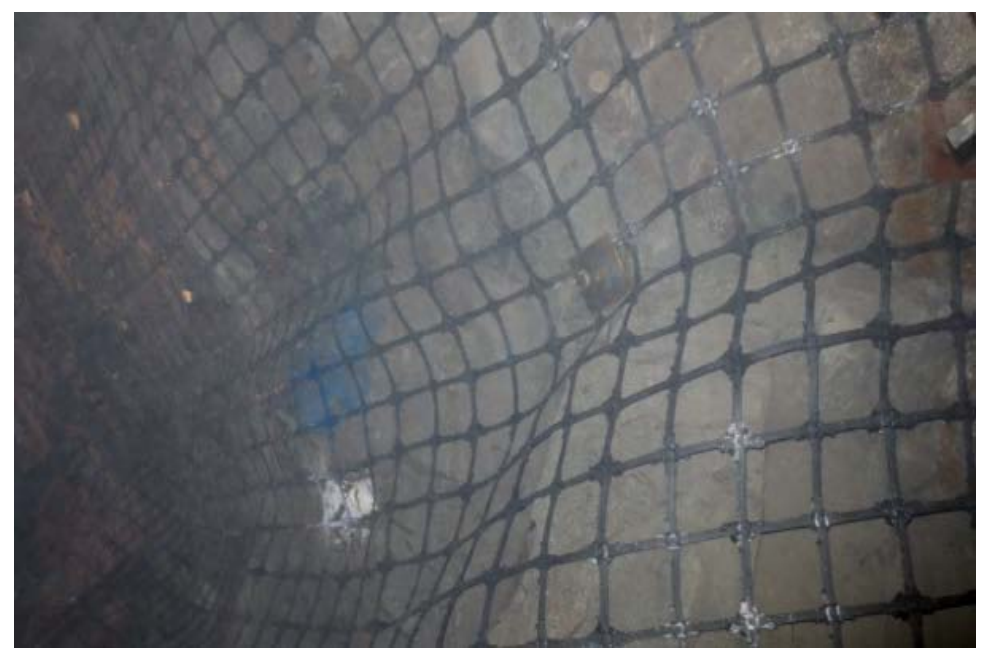

Fig. (11). Hanging geogrids.

\subsubsection{Mounting Bolt}

Generally bolt installation is achieved by means of a drill. Preparations before the installation: first of all, we should clean rock debris and water in the anchor hole by using the blower to blow wind to the hole inside. In the stage, the operator cannot stand in the same position, and they must be on the side, so as to prevent the occurrence of danger. At the bottom of the hole, anchor was fastened through a special drill, and the operator ensured that the bolts were up to the resin anchoring agent. On the other end of anchor, the steel wire mesh and anchor plate was equipped. Then through the drilling rig setting bolt, the rig was used driven by the rotation, the anchoring agent was stirred evenly, during the period of about 20 seconds, the rig was closed, and then the rig continued pressure, two minutes later, and then the nut tightening torque of $150 \mathrm{~N} \cdot \mathrm{m}$, and finally the machine was discharged.

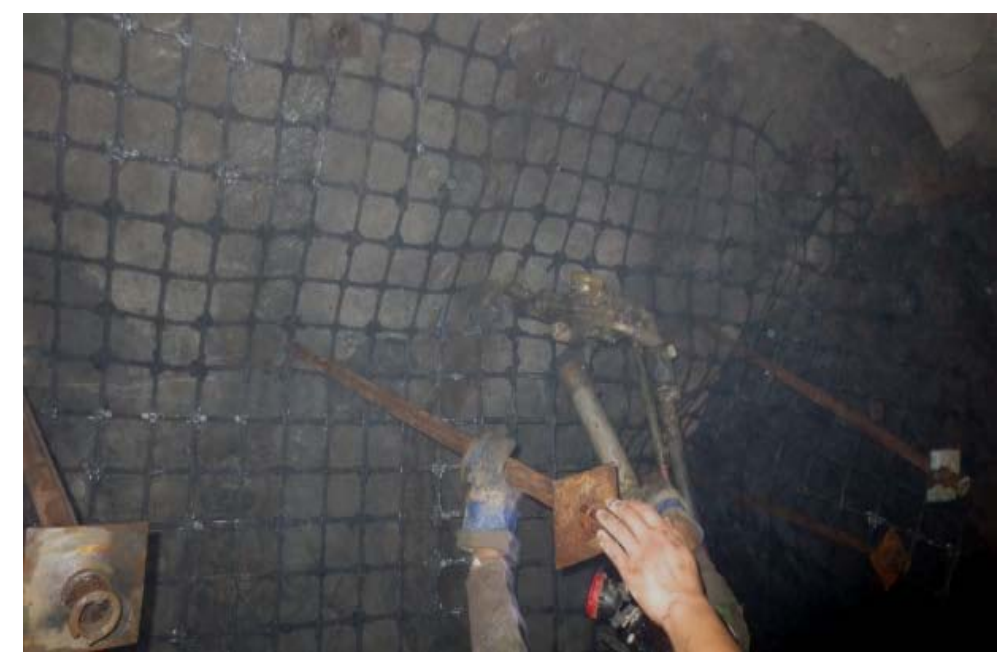

Fig. (12). Install anchor. 


\subsubsection{Jet Concrete}

In the construction of secondary lining concrete, first of all, we should check whether the bolt hit and anchor Fig. (12) net meet the design objective, and give timely feedback and process to some existing problems. When the conditions are met, the secondary lining is poured. Pouring process is the same as the initial lining.

\subsection{Analysis of Steel Grille Surrounding Rock Supporting Effect}

For the scientific evaluation of the practical effect of the supporting scheme, the monitoring of the surrounding rock deformation of the test section is needed. Among them, the deformation monitoring of surrounding rock is mainly through the test of different depth of rock mass deformation in support and reinforcement in order to understand the weakening and failure scope of surrounding rock.

\subsubsection{Multi-point Displacement Monitoring of Roof}

After test section of roadway support, a drilling was fixed in the center of the roof and equipment of multi-point displacements was installed. There were six measuring points, which included $1.0 \mathrm{~m}, 1.5 \mathrm{~m}, 2.0 \mathrm{~m}, 2.5 \mathrm{~m}, 3.0 \mathrm{~m}$ and $5.0 \mathrm{~m}$. Monitoring data with time change curves are shown in Fig. (13)

It can be seen that:

I. The accumulated displacement of the bottom wall was obvious. Thereafter, the deformation of surrounding rock was gradually attenuated. After 25 days, the deformation of the roadway floor tended to be stable.

II. After 50 days, the rock deformation and stability values were $16.0 \mathrm{~mm}, 6.5 \mathrm{~mm}, 5.5 \mathrm{~mm}, 4.0 \mathrm{~mm}, 5.0 \mathrm{~mm}$ and $3.0 \mathrm{~mm}$ at all intervals, which included $0 \sim 1.0 \mathrm{~m}, 1.0 \sim 1.5 \mathrm{~m}, 1.5 \sim 2.0 \mathrm{~m}, 2.0 \sim 2.5,2.5 \sim 3.0$, and $3.0 \sim 5.0 \mathrm{~m}$. The total displacement on the roof surface of surrounding rock reduced from $78.5 \mathrm{~mm}$ to $40.0 \mathrm{~mm}$, and the maximum separation interface transfers from the front guard roof $2.5 \mathrm{~m}$ deep to the surface of $1.0 \mathrm{~m}$.

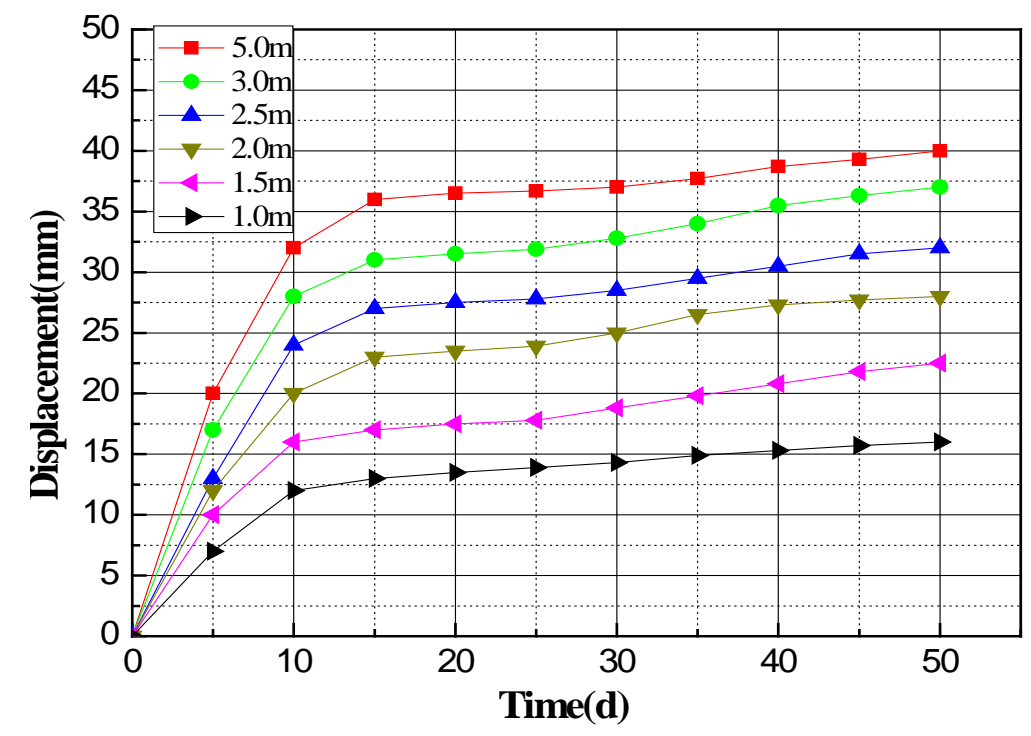

Fig. (13). The displacement curve of roof.

\subsubsection{Multi-point Displacement Monitoring of Roadway Side}

A drill hole was fixed in the test section of the roadway sides and equipment of multi-point displacements was installed. There were four measuring points, which included $1.0 \mathrm{~m}, 1.5 \mathrm{~m}, 2.0 \mathrm{~m}, 2.5 \mathrm{~m}, 3.0 \mathrm{~m}$ and $5.0 \mathrm{~m}$. Monitoring data with time change curve are shown in Fig. (14). 


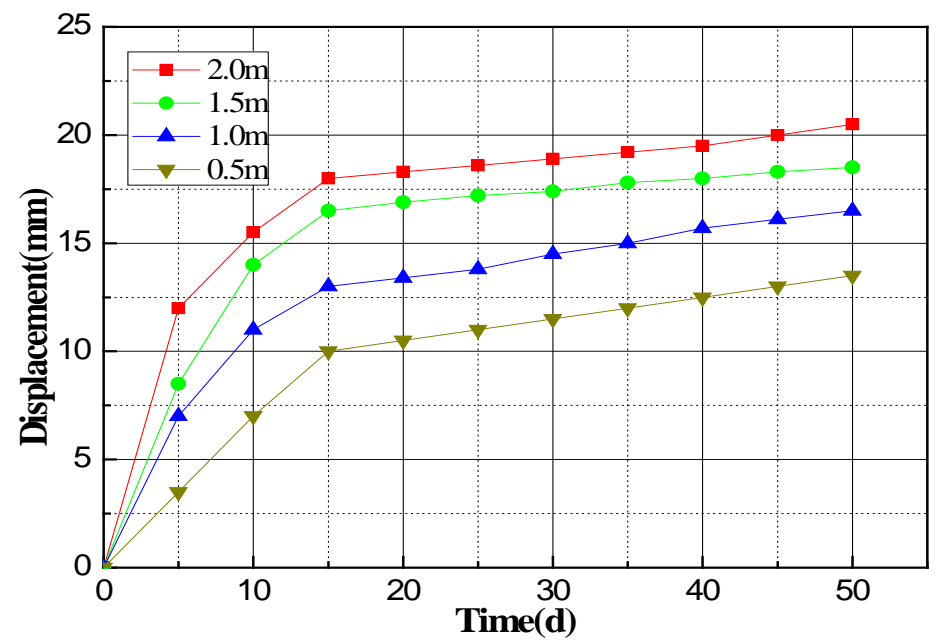

Fig. (14). The displacement curve of roadway side.

It can be seen that:

I. About 15 days after the reinforcement, the total displacement of the roadway sides increased significantly. After 15 days, the deformation of the measuring points gradually decreased and tended to be stable.

II. On the $50^{\text {th }}$ day, the rock deformation and stability values were $13.5 \mathrm{~mm}, 3.0 \mathrm{~mm}$ and $2.5 \mathrm{~mm}$ and $1.6 \mathrm{~mm}$ at intervals, which included $0 \sim 0.5 \mathrm{~m}, 0.5 \sim 1.0 \mathrm{~m}, 1.0 \sim 1.5 \mathrm{~m}, 1.5 \sim 2.0 \mathrm{~m}$. The maximum separation interface changed to the surface of $0.5 \mathrm{~m}$, and opening of the roadway sides' displacement was about $20.5 \mathrm{~mm}$. With the increasing surface distance, the displacement of surrounding rock was gradually reduced.

\subsubsection{Multi-point Displacement Monitoring of Floor}

After the test section of roadway supporting, we arranged a drill hole in central floor and installed multi-point displacement equipment. There were six measuring points, which included $1.0 \mathrm{~m}, 1.5 \mathrm{~m}, 2.0 \mathrm{~m}, 2.5 \mathrm{~m}, 3.0 \mathrm{~m}$ and $5.0 \mathrm{~m}$. Monitoring data with time change curve is shown in Fig. (15).

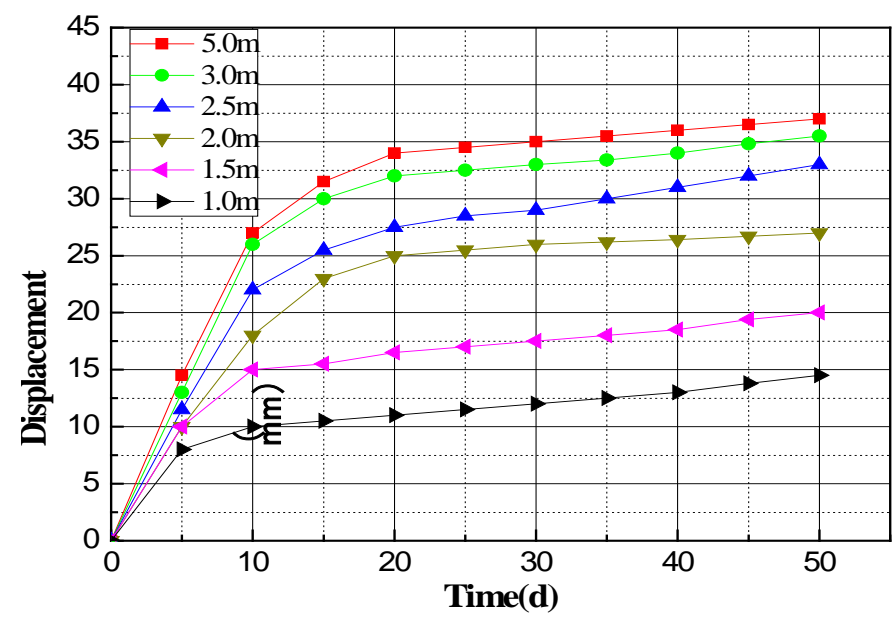

Fig. (15). The displacement curve of floor.

It can be seen that:

I. The total displacement of the bottom wall in the $25 \mathrm{~d}$ increased obviously after the reinforcement. Thereafter, the deformation of surrounding rock was gradually attenuated. After 30 days, the floor of the roadway tended to be stable.

II. On the $50^{\text {th }}$ day, less than $1.0 \mathrm{~m}$, in $1.0 \sim 1.5 \mathrm{~m}, 1.5 \sim 2.0 \mathrm{~m}, 2.0 \sim 2.5 \mathrm{~m}, 2.5 \sim 3.0 \mathrm{~m}$, and $3.0 \sim 5.0 \mathrm{~m}$, the rock deformation 
and stability values were $14.5 \mathrm{~mm} 5.5 \mathrm{~mm}$ and $7.0,6.0 \mathrm{~mm}$ and $2.5 \mathrm{~mm}$ and $1.5 \mathrm{~mm}$. Maximum separation interface with a front protection plate deeply transferred to a surface of $1.0 \mathrm{~m}$.

The orifice of the surface of the base plate of the surrounding rock displacement was about $37.0 \mathrm{~mm}$. The distance from the surface of the bottom plate is gradually reduced, the deformation of the surrounding rock displacement which were less than 1.0 and $1.0 \sim 1.5 \mathrm{~m}$, accounting for $39.2 \%$ and $14.8 \%$ in total displacement. $1.5 \sim 2.0 \mathrm{~m}, 2.0 \sim 2.5,2.5 \sim 3.0 \mathrm{~m}$, $3.0 \sim 5.0 \mathrm{~m}$ rock deformation accounted for the total displacement capacity of $19.0 \%, 16.2 \%, 6.8 \%$ and $4.0 \%$ respectively.

\subsection{Effect Evaluation}

Through above mine supporting analysis in Hualian, the data showed that the deformation tended to be stable in supporting 25 days. After supporting 50 days, the maximum displacement of the roof was 40mm, maximum displacement of the side was $20.5 \mathrm{~mm}$, the maximum displacement of the floor was $37 \mathrm{~mm}$, and the maximum deformation speed only was $0.8 \mathrm{~mm} / \mathrm{d}$. The roadway is in a steady state, and the supporting effect was good.

\section{CONCLUSION}

1. Steel-plastic geogrid has better deformation resistant structure, twisted nodes and possesses roadway surrounding rock deformation settlement ability, high flexibility, high elasticity, nodes are not easy to be torn to support a multi direction load, and have a great effect on disperse loading,which has good tensile property, creep property and deflection performance.

2. Steel-plastic geogrid and high-strength prestresses anchor combined support apply enough pre tightening force to the rock, improving the stress state of surrounding rock, controlling the deformation of surrounding rock effectively, and reducing the cost of support. Steel-plastic geogrid plays an important role in roadway supporting.

\section{CONFLICT OF INTEREST}

The authors confirm that this article content has no conflict of interest.

\section{ACKNOWLEDGEMENTS}

This work was financially supported by:

(1) National Natural Science Foundation of China (NSFC) (41372289).

(2) SDUST Research Fund (2014TDJH103).

\section{REFERENCES}

[1] C.O. Aksoy, O. Zacar, and V. Kantarci, "An example for estimation of rock mass deformations around an underground opening by numerical modeling", Int. J. Rock Mech. Min. Sci., vol. 47, pp. 272-280, 2010. [http://dx.doi.org/10.1016/j.ijrmms.2009.12.001]

[2] D. Zhao, G. Swoboda, and F. Laabmayr, "Damage mechanics and its application for the design of an underground theater", Tunn. Undergr. Space Technol., vol. 19, pp. 567-575, 2004.

[http://dx.doi.org/10.1016/j.tust.2004.01.004]

[3] V. Hajiabdolmajid, P.K. Kaiser, and C.D. Martin, "Modelling brittle rock failure", Int. J. Rock Mech. Min. Sci., vol. 39, no. 6, pp. 731-141, 2002 . [http://dx.doi.org/10.1016/S1365-1609(02)00051-5]

[4] D.D. Tannant, "Load capacity and stiffness of welded wire, chain link and expanded metal mesh", In: Chapter 46 in Surface Support in Mining., Melbourne: Australian Center for Geomechanics, 2004, pp. 387-390.

[5] D.D. Tannant, P.K. Kaiser, and S. Maloney, Load-displacement Properties of Welded-wire, Chain-link and Expand Metal Mesh International Symposium on Rock Support., Norway, pp. 651-659, 1997.

[6] H. Witthaus, and N. Polysos, "Applied geomechanics for support design in German deep coal mines", In: Proceedings of the 25th International Conference on Ground Control in Mining [C]., West Virginia: Morgantown, 2006.

[7] W.F. Bawden, and J.D. Tod, "Optimization of cable bolt ground support using SMART instrumentation", ISRM News J., vol. 7, no. 3, pp. 10-16, 2003. 
[8] B. Liu, Z.Q. Yue, and L.G. Tham, "Analytical design method for a truss-bolt system for reinforcement of fractured coal mine roofs-illustrated with a case study", Int. J. Rock Mech. Min. Sci., vol. 42, no. 2, pp. 95-218, 2005.

[9] R.K. Brummer, and G.R. Swan, "Support and Structural Use of Shotcrete in Mines", In: W.A. Hustrulid and R.L. Bullock Ed., Underground Mining Methods Engineering Fundamentals and International Case Studies, Society for Mining, Metallurgy and Exploration: Littleton, Colorad, 2001, pp. 593-600.

[10] B.J. Holmgren, "Shotcrete linings in hard rock", In: W.A. Hustrulid, and R.L. Bullock, Eds., Underground Mining Methods: Engineering Fundamentals and International Case Studies., Society for Mining, Metallurgy and Exploration: Littleton, Colorado, 2001 , pp. $569-577$.

[11] P.K. Kaiser, and D.D. Tannant, "The role of shotcrete in hard-rock mines", In: W.A. Hustrulid, and R.L. Bullock, Eds., Underground Mining Methods: Engineering Fundamentals and International Case Studies., Society for Mining, Metallurgy and Exploration: Littleton, Colorado, 2001, pp. 579-592.

[12] S. Spearing, "Shotcrete as an underground support material", In: W.A. Hustrulid, and R.L. Bullock, Eds., Underground Mining Methods: Engineering Fundamentals and International Case Studies., Society for Mining, Metallurgy and Exploration: Littleton, Colorado, 2001, pp. 563-568.

[13] E. Villaescusa, "An Australian perspective to grouting for cablebolt reinforcement", In: E. Villaescusa, C. R. Windsor, and A. G. Thompson, Eds., Proc. Int. Symp. Rock Support, Kalgoorlie, Balkema: Rotterdam, pp. 91-102, 1999.

[14] P.G. Fuller, "Roof strata reinforcement-achievements and challenges", In: E. Villaescusa, C. R. Windsor, and A. G. Thompson, Eds., Proc. Int. Symp. Rock Support, Kalgoorlie, Balkema: Rotterdam, pp. 405-415, 1999.

[15] L.I. Jian, and S.U. Zhiyong, "Laboratory studies on mechanical performance and supporting function of bolt metal meshes", J. China Coal Soc, vol. 38, no. 9, pp. 1542-1548, 2013.

[16] D.E. Xaolin, "Optimization and management of anchor mesh supporting technique for deep coal tunnel", Coal Mining Technol., vol. 10, no. 6, pp. 50-51, 2005.

[17] W.A. Qingbiao, "Steel plastic geogrid performance testing and its application in the reduction of spring back of shotcrete", The Open Const. Buil. Technol. J., vol. 9, no. 6, pp. 223-229, 2015.

[18] W.A. Qingbiao, "The research and development of safety forewarning composite integral strong geocell", Mat. Sci. J., vol. 9, pp. 139-145, 2015 .

[19] W.A. Qingbiao, "The mechanical property of bidirectional geogrid and its application research in retaining wall design", The Open Construct. Buil. Technol. J., vol. 9, pp. 214-222, 2015.

[20] W.A. Qingbiao, and L.Ü. Rongshan, "Experimental study of tensile properties of the steel-plastic geogrids", Mat. Sci. J., vol. 9, pp. 146-151, 2015 .

[21] S.U. Xiaoming, Y.A. Jun, and C.A. Wufu, "Research on space-time action rule of bolt-net-anchor coupling support for deep gateway", Chinese J. Rock Mech. Eng., vol. 26, no. 5, pp. 895-900, 2007.

[22] G.U. Junhui, C.H. Weiguo, and Z.H. Bin, "Research on creep property of geogrids at a low temperature", Rock Soil Mech., vol. 30, no. 10, pp. 3009-3012, 2009.

[23] L.U. Maotian, X.I. Chengzhi, and Y.A. Qing, "An experimental study on the creep behavior of geogrids under long-term external loading", China Civil Eng. J., vol. 39, no. 4, pp. 87-91, 2006

[24] X.L. Yang, and F. Huang, "Collapse mechanism of shallow tunnel based on nonlinear Hoek-Brown failure criterion", Tunn. Undergr. Space Technol., vol. 26, pp. 686-691, 2011. [http://dx.doi.org/10.1016/j.tust.2011.05.008]

[26] F. Huang, and X.L. Yang, "Upper bound limit analysis of collapse shape for circular tunnel subjected to pore pressure based on the HoekBrown failure criterion", Tunn. Undergr. Space Technol., vol. 26, pp. 614-618, 2011. [http://dx.doi.org/10.1016/j.tust.2011.04.002]

[26] M. Fraldi, and F. Guarracino, "Analytical solutions for collapse mechanisms in tunnels with arbitrary cross sections", Int. J. Solids Struct., vol. 47, no. 2, pp. 216-223, 2010.

[http://dx.doi.org/10.1016/j.ijsolstr.2009.09.028]

[27] M.S. Diederichs, and P.K. Kaiser, "Stability of large excavations in laminated hard rock massesahe voussoir analogue revisited", Int. J. Rock Mech. Min. Sci., vol. 36, no. 1, pp. 97-117, 1999. [http://dx.doi.org/10.1016/S0148-9062(98)00180-6]

[28] M. Caia, P.K. Kaisers, Y. Tasakab, and M. Minamic, "Determination of residual strength parameters of jointed rock masses using the GSI system", Int. J. Rock Mech. Min. Sci., vol. 44, no. 2, pp. 247-265, 2007. [http://dx.doi.org/10.1016/j.ijrmms.2006.07.005]

[29] F. Varas, E. Alonso, and L.R. Alejano, "Study of bifurcation in problem of unloading a circular excavation in a strain-softening material", Tunn. Undergr. Space Technol., vol. 20, no. 5, pp. 311-322, 2005.

[http://dx.doi.org/10.1016/j.tust.2004.12.003]

[30] K. Susantha, H. Ge, and T. Usami, "Uniaxial stress-strain relationship of concrete confined by various shaped steel tubes", Eng. Struct., vol. 23, pp. 1331-1378, 2001 .

[http://dx.doi.org/10.1016/S0141-0296(01)00020-7] 
[31] E. Inai, A. Mukai, M. Kai, H. Tokinoya, T. Fulcumoto, and K. Mori, "Behaviour of concrete-filled steel tube beam columns", J. Struct. Eng., vol. 130, no. 2, pp. 189-202, 2004. [http://dx.doi.org/10.1061/(ASCE)0733-9445(2004)130:2(189)]

[33] T. Fujimoto, A. Mukai, I. Nishiyama, and K. Sakino, "Behavior of eccentrically loaded concrete-filled steel tubular columns", J. Struct. Eng., vol. 130, no. 2, pp. 203-215, 2004 [http://dx.doi.org/10.1061/(ASCE)0733-9445(2004)130:2(203)]

[34] J.Y. Liew, T.H. Teo, and N.E. Shanmugam, "Composite joints subject to reversal of loading Part 1:Experimental study", J. Construct. Steel Res., vol. 130, no. 2, pp. 221-246, 2004. [http://dx.doi.org/10.1016/j.jcsr.2003.08.010]

[35] A.P. Gardner, and H.M. Goldsworthy, "Experimental investigation of the stiffness of critical components in a moment-resisting composite connection", J. Construct. Steel Res., no. 61, pp. 709-735, 2005. [http://dx.doi.org/10.1016/j.jcsr.2004.11.004]

[36] H.M. Goldsworthy, and A.P. Gardner, "Feasibility study for blind-bolted connections to concrete-filled circular steel tubular columns", Struct. Eng. Mech., no. 62, pp. 463-478, 2006. [http://dx.doi.org/10.12989/sem.2006.24.4.463]

[37] H.Y. Loh, B. Uy, and M.A. Bradford, "The effects of partial shear connection in composite flush end plate joints: Part I Experimental study", J. Construct. Steel Res., no. 62, pp. 378-390, 2006. [http://dx.doi.org/10.1016/j.jcsr.2005.07.012]

[38] H. Witthaus, N. Polysos, and H. Witthaus, "The effects of partial shear connection in composite flush end plate joints: Part I Experimental study", J. Construct. Steel Res., vol. 62, pp. 378-390, 2006.

[39] W.F. Bawden, "Optimization of cable bolt ground support using SMART instrumentation", ISRM News J., vol. 7, no. 3, pp. 10-16, 2003.

[40] B. Liu, Z.Q. Yue, and L.G. Tham, "Analytical design method for a truss-bolt system for reinforcement of fractured coal mine roofs-illustrated with a case study", Int. J. Rock Mech. Min. Sci., vol. 42, no. 2, pp. 195-218, 2005. [http://dx.doi.org/10.1016/j.ijrmms.2004.08.006]

[41] L.U. Mao-tian, X.I. Chengzhi, and Y.A. Qing, "Experimental study on creep properties and viscoelasticity constitutive relationship for geogrids", Rock Soil Mech., vol. 26, no. 2, pp. 187-292, 2005.

[42] G.A. Shun-ping, "Research on the acting mechanism and application of metal net in bolt net support", J. North China Institute Sci. Technol., vol. 1, no. 4, pp. 73-74, 2004.

[43] Z.H. Xingdong, and T.A. Chun'an, "Research on bolt-netting support under high stressed and fractured rockmass", Rock soil Mech., vol. 27, no. 2, pp. 918-920, 2006.

(c) Wang et al.; Licensee Bentham Open

This is an open access article licensed under the terms of the Creative Commons Attribution-Non-Commercial 4.0 International Public License (CC BY-NC 4.0) (https://creativecommons.org/licenses/by-nc/4.0/legalcode), which permits unrestricted, non-commercial use, distribution and reproduction in any medium, provided the work is properly cited. 